\title{
EFEK PENGADUKAN SAAT PELAPISAN TEMBAGA PADA ALUMUNIUM TERHADAP LAJU KOROSI
}

\author{
${ }^{1)}$ Syamsuir, 1)Hamzah Fajar, ${ }^{1}$ Kurniawan Widodo \& ${ }^{2}$ Sopiyan \\ ${ }^{1)}$ Program Studi Teknik Mesin, Fakultas Teknik, Universitas Negeri Jakarta \\ ${ }^{2)}$ Program Studi Pendidikan Vokasional Teknik Mesin, Fakultas Teknik, Universitas Negeri \\ Jakarta
}

E-mail:syam_tjg@yahoo.com

\begin{abstract}
ABSTRAK
Penggunaan alumunium yang dilapis tembaga akan lebih ekonomis jika dibandingkan dengan pengunaan tembaga pejal. Saat ini penggunaan tembaga dalam dunia medis banyak dibutuhkan,karena dapat berfungsi sebagai anti bakteri (oligodinamik). Dalam penelitian ini akan dilakukan proses elektroplating dengan pelapis tembaga di atas substrat alumunium. Pada proses elektroplating tersebut akan ditambahkan juga proses pengadukan sebesar 300 rpm. Hal ini dilakukan agar distribusi ion merata. Pada proses elektroplating tembaga menggunakan kuat arus $20 \mathrm{~mA}$,voltase 1,2 V selama 30 menit dengan komposisi larutan $\mathrm{CuSO}_{4} 220 \mathrm{gr} / \mathrm{L}$ dan $\mathrm{H}_{2} \mathrm{SO}_{4}$ 20ml/L. Bedasarkan hasil uji korosi yang di dapat dengan diaduk maka laju korosinya meningkat. Laju korosi terendah pada substrat yang telah di lapisi dengan tembaga tanpa pengadukan. Terlihat pergeseran potensial korosi (Ekorosi) sekitar $\pm 0,4 \mathrm{~V}$ ketika dilapisi dengan tembaga, baik dengan pengadukan maupun tidak. Permukaan lapisan tembaga terlihat lebih seragam ketika dilakukan pengadukan saat proses elektroplating.
\end{abstract}

Kata kunci : Elektroplating,Tembaga, Nikel, Alumunium, Magnetic stirrer

The use of copper coated aluminum will be more economical when compared to the use of solid copper. Currently the use of copper in the medical world is needed, because it can be used as an anti-bacterial (oligodynamic). In this research an electroplating process will be carried out with a copper coating on an aluminum substrate. The electroplating process will also add a stirring process of $300 \mathrm{rpm}$. This is done so that the ion distribution is evenly distributed. In the copper electroplating process using a strong current of $20 \mathrm{~mA}$, a voltage of $1.2 \mathrm{~V}$ for 30 minutes with a composition of $220 \mathrm{gr} / \mathrm{L}$ $\mathrm{CuSO}_{4}$ solution and $2 \mathrm{Oml} / \mathrm{L} \mathrm{H}_{2} \mathrm{SO}_{4}$ based on corrosion test results that can be stirred so that the corrosion increases. The lowest corrosion rate on substrates that have been coated with copper without stirring. Corrosion corrosion potential (Ekorosi) around $\pm 0.4 \mathrm{~V}$ is complicated by copper, either by stirring or not. The surface of the copper layer looks more uniform when stirring during the electroplating process.

Keywords: Electroplating, Copper, Nickel, Aluminum, Magnetic stirrer

\section{Pendahuluan}

Elektroplating merupakan salah satu metode dari pelapisan logam yang juga disebut elektrodeposisi, yaitu suatu proses deposisi logam pelindung di atas logam lain dengan cara elektrokimia. Logam-logam yang dapat digunakan sebagai pelapis adalah tembaga, nikel dan lain-lain [1]. Logam-logam pelapis tersebut dapat digunakan untuk melapisi logam seperti alumunium [2]. Alumunium juga memiliki berat yang ringan jika di bandingkan material yang lain. Penggunaan alumunium yang dilapis tembaga akan lebih ekonomis jika dibandingkan dengan pengunaan tembaga pejal. Saat ini penggunaan tembaga dalam dunia medis banyak dibutuhkan, karena dapat berfungsi sebagai anti bakteri (oligodinamik) [3].

Hasil pelapisan logam dengan metode elektroplating akan berpengaruh dengan ditambahkan nya beberapa faktor, salah satunya yaitu dengan pengaduk. Ion-ion positif yang dilepaskan dari anoda akan lebih teratur pergerakannya karena pengaruh pengaduk. Untuk meratakan distribusi ion nikel agar supaya ketebalan yang diperoleh sama maka dalam proses elektroplating dibutuhkan pengaduk dengan mengunakan udara dengan cara dihembuskan melalui kompresor kedalam elektrolit [4]. Namun hal ini bisa juga secara mekanik yaitu diaduk langsung dengan menggunakan pengaduk. Proses pengadukan juga dapat meningkatkan efesiensi arus dalam proses elektroplating [5]. Dalam penelitian ini akan dilakukan proses elektroplating dengan pelapis tembaga pada substrat alumunium dengan diberikan proses pengadukan. 


\section{Metodologi}

Proses pengujian Pelapisan dengan metode elektroplating dengan pengaruh pengadukan tergambar dalam flow chart sebagai berikut :

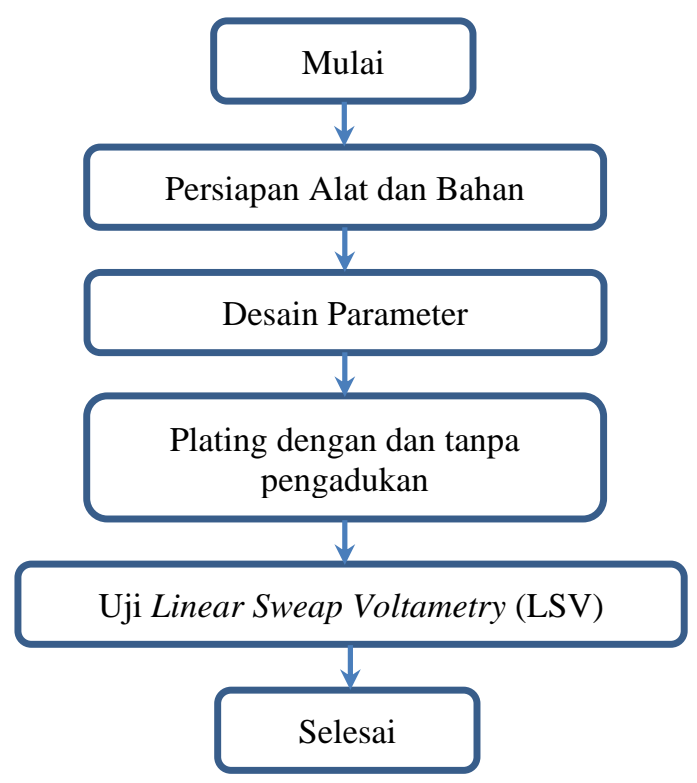

Gambar 2.1 Proses Penelitian

\subsection{Alat dan Bahan}

Alat - alat yang diperlukan untuk melakukan penelitian pelapisan tembaga adalah sebagai berikut:

Tabel 2.1 Daftar Alat Penelitian

\begin{tabular}{|c|l|c|}
\hline No & \multicolumn{1}{|c|}{ Alat } & Jumlah \\
\hline 1 & DC Power Supply 20V & 1 set \\
\hline 2 & Anoda Tembaga & 1 buah \\
\hline 3 & Magnetic Stirrer & 1 set \\
\hline 4 & Timbangan & 1 set \\
\hline 5 & Pipet & 1 buah \\
\hline 7 & Multimeter & 1 set \\
\hline 8 & Gelas Beaker $1000 \mathrm{~mL}$ & 2 buah \\
\hline 9 & Amplas berbagai ukuran & 5 buah \\
\hline 10 & Kain & 1 lembar \\
\hline 11 & Tang & 1 buah \\
\hline 12 & Kabel & $1 \mathrm{~m}$ \\
\hline
\end{tabular}

\subsection{Parameter pelapisan}

a. Pelapisan Tembaga

Tabel 2.2 Komposisi Larutan Pelapisan Tembaga
\begin{tabular}{|c|l|l|}
\hline No & \multicolumn{1}{|c|}{ Bahan Kimia } & Jumlah \\
\hline 1 & $\mathrm{CuSO}_{4}$ ( Tembaga Sulfat ) & $110 \mathrm{gr}$ \\
\hline 2 & $\mathrm{H}_{2} \mathrm{SO}_{4}$ ( Asam Sulfat) & $10 \mathrm{ml}$ \\
\hline 3 & Aquades & $500 \mathrm{ml}$ \\
\hline
\end{tabular}


Kondisi operasi :
1. $\mathrm{pH}$
: Asam ( <7 )
2. Temperatur : Kondisi ruang $\left(32^{\circ} \mathrm{C}\right)$
3. Kuat arus : $20 \mathrm{~mA}$
4. Voltase $: 1,2 \mathrm{~V}$
5. Waktu : 30 menit

b. Desain pelapisan

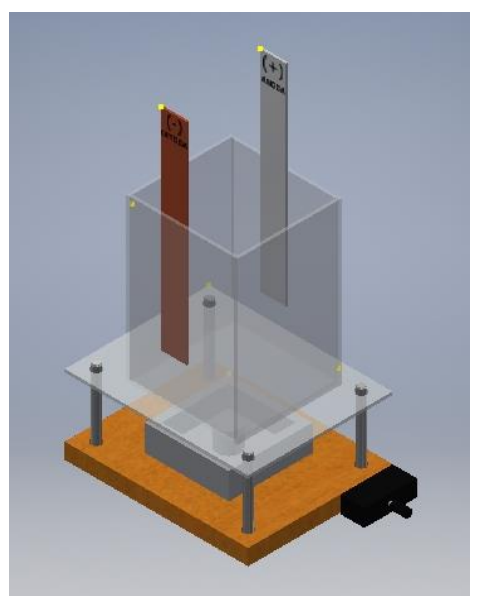

Gambar 2.2 Magnetic Stirrer Pada Proses Pelapisan

Pada pembahan pengaduk saat proses pelapisan digunakan magnetic stirrer, penggunaan magnetic stirrer dengan kecepatan $\pm 300 \mathrm{rpm}$ di gunakan sepanjang proses elektroplating itu sendiri.

\section{Hasil dan Pembahasan}

\subsection{Hasil Foto Makro}

Sebagai berikut merupakan foto makro hasil elektroplating tembaga yang di fabrikasi dengan maupun tanpa proses pengadukan.

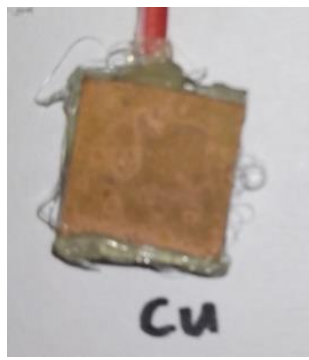

(a)

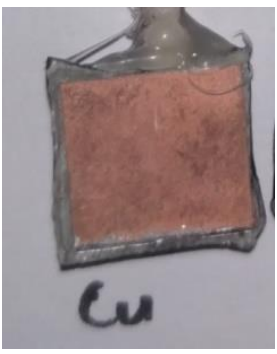

(b)

Gambar 3.1 Foto Makro hasil elektroplating (a) tembaga tanpa pengadukan (b) tembaga dengan pengadukan

Dari gambar di atas dapat terlihat, dengan pengadukan saat fabrikasi lapisan, akan menghasilkan permukaan yang seragam. Permukaan yang seragam ini dikarenakan proses pemindahan ion dari anoda tembaga ke katoda alumunium dipaksa teratur karena adanya proses pengadukan.

\subsection{Hasil Uji Korosi dengan LSV}

Hasil uji korosi dengan LSV dalam larutan 3,5\% $\mathrm{NaCl}$ dimana elekroda referensi menggunakan $\mathrm{Ag} / \mathrm{AgCl}$, dan elektroda konter menggunakan platinum (Pt). Dari hasil pengujian didapatkan pengukuran arus korosi (I korosi) serta potensial korosi (V). Dengan memasukkan ke dalam rumus [6]:

$$
\text { Laju Korosi }=C \frac{M \times i}{n \times \rho}
$$


Dimana: Laju Korosi $=(m m p y), C=3,27, i=$ rapatarus $\left(\frac{A}{\mathrm{~cm}^{2}}\right), M=$ masa atom $\left(\frac{\mathrm{g}}{\mathrm{mol}}\right), n=$ jumlah elektron dan $\rho=$ massa jenis $\left(\frac{\mathrm{g}}{\mathrm{cm}^{3}}\right)$ bawah ini.

Maka didapatkan hasil laju korosi dalam mmpy. Lebih lengkap dapat dilihat pada tabel 3.1 di Tabel 3.1. Hasil Pengujian LSV

\begin{tabular}{|c|l|c|c|c|}
\hline No & \multicolumn{1}{|c|}{ Sampel } & I Korosi (A) & E Korosi (V) & Laju Korosi (mmpy) \\
\hline 1 & Al Substrat & 0,0001068 & $-1,328$ & 1,751 \\
\hline 2 & $\mathrm{Cu}$ & 0,0000182 & $-0,958$ & 0,1979 \\
\hline 3 & $\mathrm{Cu}$ stirrer & 0,0000346 & $-0,934$ & 0,3768 \\
\hline
\end{tabular}

Dari tabel 3.1 dapat terlihat bahwa laju korosi terendah pada substrat yang telah di lapisi dengan tembaga tanpa pengadukan. Ketika diberikan pengadukan pada proses pelapisan tembaga maka laju korosi meningkat dari 0.1979 mmpy menjadi $0.3768 \mathrm{mmpy}$. Akan tetapi potensial lebih ke arah positif dari -0,958 $\mathrm{V}$ menjadi $-0,934 \mathrm{~V}$.

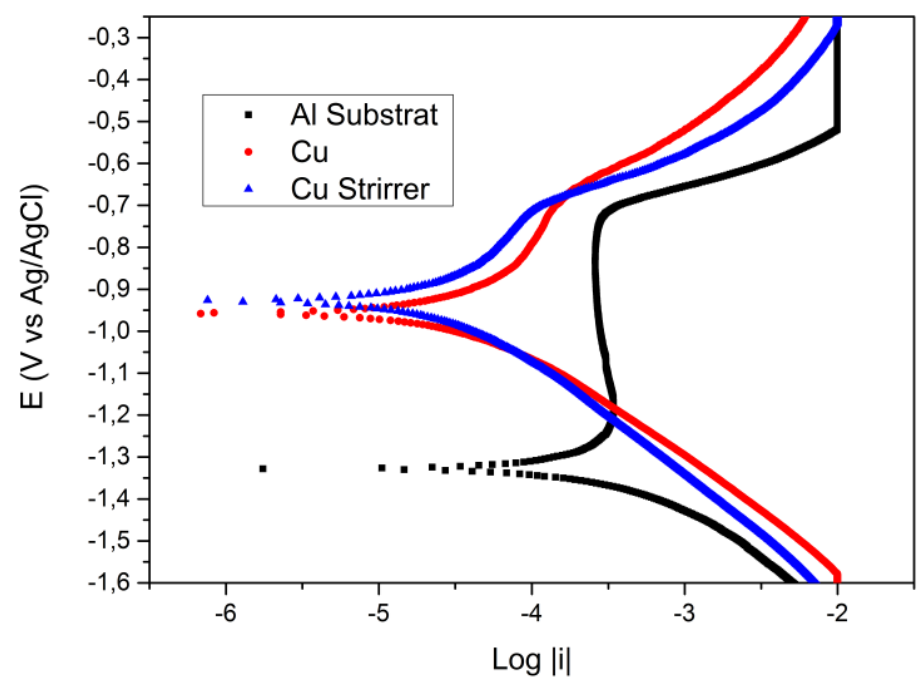

Gambar 3.1 Hasil pengukuran LSV

Berdasarkan gambar 3.1 dapat terlihat pergeseran potensial korosi ( $\mathrm{E}_{\text {korosi }}$ ) sekitar $\pm 0,4 \mathrm{~V}$ ketika dilapisi dengan tembaga, baik dengan pengadukan maupun tidak.

\section{Kesimpulan \& Saran}

Dari penelitian yang sudah dilakukan, maka dapat disimpulkan laju korosi terendah pada substrat yang telah di lapisi dengan tembaga tanpa pengadukan. Terlihat pergeseran potensial korosi (E $\left.\mathrm{E}_{\mathrm{korosi}}\right)$ sekitar $\pm 0,4 \mathrm{~V}$ ketika dilapisi dengan tembaga, baik dengan pengadukan maupun tidak. Permukaan lapisan tembaga terlihat lebih seragam ketika dilakukan pengadukan saat proses elektroplating.

\section{Daftar Pustaka}

1. Sudana, I. M., Arsani, I. A. A., \& Waisnawa, I. S. (2017). Alat Simulasi Pelapisan Logam Dengan Metode Elektroplating. Logic: Jurnal Rancang Bangun dan Teknologi, 14(3), 190.

2. Susetyo, F. B., Situmorang, E. M., Luthfiya, S., \& Soegijono, B. (2018). Copper Electrodeposition onto Aluminum from a Copper Acid Baths In The Presence Of Poly Ethylene Glycol (PEG). In MATEC Web of Conferences (Vol. 218, p. 04026). EDP Sciences.

3. Manikandan, A., \& Sathiyabama, M. (2015). Green synthesis of copper-chitosan nanoparticles and study of its antibacterial activity. Journal of Nanomedicine \& Nanotechnology, 6(1), 1. 
4. Sugiyarta, S., Bayuseno, A. P., \& Nugroho, S. (2012). Pengaruh konsentrasi larutan dan kuat arus terhadap ketebalan pada proses pelapisan nikel untuk baja karbon rendah. ROTASI, 14(4), 23-27.

5. Amigato, A. F. A. A. F., \& Marwati, S. M. S. (2016). Optimasi Potensial, Suhu Larutan, Dan Pengaruh Pengadukan Pada Elektrodeposisi Ion Logam Ag (I) Dalam Limbah Cair Elektroplating Dengan Menggunakan Agen Pereduksi Formaldehida. Jurnal Kimia Dasar, 5(1).

6. Ahmad, Z. (2006). Principles of corrosion engineering and corrosion control. Elsevier. 